\title{
EROTISMO Y PERVERSIÓN: UN DIÁLOGO ENTRE PSICOANÁLISIS Y FILOSOFÍA
}

\author{
EROTICISM AND PERVERSION: \\ A DIALOGUE BETWEEN PSYCHOANALYSIS AND PHILOSOPHY
}

\author{
Francisco Javier De Santiago Herrero \\ Universidad de Salamanca, \\ Salamanca - España.
}

Alejandra Lin Ku*

Asociación Psicoanalítica Kairós, Salamanca - España.

\section{Montfragüe Garcia-Mateos}

Facultad de Educación, Universidad Pontificia de Salamanca,

Salamanca - España.

Recibido octubre de 2018/Received October, 2018

Aceptado enero de 2019/Accepted January, 2019

\begin{abstract}
RESUMEN
El presente artículo es una tentativa de aproximación y comprensión del erotismo como parte inherente de la naturaleza del ser humano, prestando especial atención a su forma más extrema: la perversión. Para ello hemos recurrido a la reflexión psicoanalítica de escritos de importantes filósofos, pues el erotismo se extiende a toda la realidad humana y, como tal, hallaremos más respuestas (y nuevas preguntas) en la conjunción entre varios campos del saber. Así pues, se trata de un estudio acerca del erotismo a través del diálogo entre psicoanálisis y filosofía.
\end{abstract}

Palabras Clave: Erotismo, filosofía, perversión, psicoanálisis, Sade, sadismo, sexualidad.

\begin{abstract}
The present article is a tentative of approximation and comprehension to the eroticism as an inherent part of human nature, paying particular attention to its most extreme form: perversion. In order to accomplish that, we resorted to the psychoanalytic reflection of writings from important philosophers, since eroticism extends itself to the whole human reality and, as such, we will find more answers (and new questions) in the conjunction between several fields of knowledge. Hence, it is a study about erotism via the dialogue between psychoanalysis and philosophy.
\end{abstract}

Key Words: Eroticism, perversion, philosophy, psychoanalysis, Sade, sadism, sexuality.

\section{INTRODUCCIÓN}

El presente artículo es una investigación acerca del erotismo humano y sus expresiones, poniendo especial énfasis en su forma más extrema: la perversión. Es también un intento de enriquecer la teoría psicoanalítica con el aporte de la filosofía pues, aunque como cabe esperar, existen puntos de desacuerdo que dificultan aún más el entendimiento, la confluencia de ambos campos del saber abre posibles respuestas y nuevas miras.

* Autor correspondiente / Correspondig author: alejandralinku@gmail.com 
Hemos tomado como eje central de nuestro trabajo la reflexión de varios de los pensadores más relevantes del siglo XX respecto a la temática a tratar: George Bataille, Pierre Klossowski y Maurice Blanchot. A través de sus obras y enseñanzas hemos podido recorrer un trayecto que comienza con la exploración del erotismo, su surgimiento, sus manifestaciones y su íntima relación con la muerte, la belleza, el deseo, la sacralidad, la prohibición y la transgresión.

Tras indagar en lo que podríamos denominar sexualidad normal en el ser humano, nos adentraremos en el pensamiento del marqués de Sade como máximo exponente de la perversión, no tanto en el nivel práctico, sino en el teórico, pues Sade llevó la depravación (dentro y fuera del terreno sexual) más allá de la conducta y lo convirtió en un sistema: un legado moral.

Este estudio es, en suma, un encuentro entre el psicoanálisis y la filosofía en torno al erotismo y la perversión.

\section{EL EROTISMO}

\subsection{Erotismo y Muerte}

A diferencia del resto de especies animales, el hombre tiene conciencia de su propia muerte. La finitud cae sobre nosotros como una losa pesada de pavor, incertidumbre e indefensión, pero también nos despierta de nuestra ceguera y nos posibilita una visión más plena y enriquecida de la vida. Salimos de la indiferencia para aprehender y construir significados, para traspasar el letargo. Le decimos que no al movimiento de la Naturaleza en busca de algo más. Ser conocedores de nuestra temporalidad cambia necesariamente nuestra posición frente al mundo, frente a nosotros mismos, y también frente a nuestra sexualidad.

Surge así el erotismo, aquello que nos separa de la animalidad y que a su vez nos conecta con nuestra naturaleza instintiva, porque la sexualidad humana no elimina la sexualidad animal, sino que, partiendo de ella y conservándola en sí, la supera. El erotismo no nos viene dado de fuera; debe ser reconocido por un sujeto, vivenciado como experiencia interior. Escapamos así, mediante el erotismo, de los límites genéticos y jugamos más allá, donde existe cierta libertad de elección, de comportamiento, de placer. El fin último no es ya la procreación, sino la voluptuosidad, pues cuando se cruza la frontera de la biología ya no estamos bajo el amparo del equilibrio natural, sino que nos encontramos necesariamente en el terreno del desorden y el exceso.

Erotismo y muerte van por tanto de la mano. Dice Bataille al respecto: "el erotismo surge de la dialéctica entre lo continuo (ser) y lo discontinuo (el sujeto) que experimenta el deseo de continuidad (que no puede sino ser deseo de muerte)" (Bataille, 1981, p. 10). El ser humano, ante la conciencia de su propia finitud, se enfrenta con la soledad y la fragilidad de su existencia particular. Para combatir esta angustia se arroja en la búsqueda tormentosa de la plenitud, sólo posible mediante la fusión con una totalidad, es decir, con la destrucción del sujeto. Y es que lo que está en juego en el erotismo es siempre una disolución de las formas constituidas; a través del erotismo los seres pasan de la discontinuidad a la continuidad mediante la obscenidad.

Ese abismo es profundo; no veo qué medio existiría para suprimirlo. Lo único que podemos hacer es sentir en común el vértigo del abismo. Puede fascinarnos. Ese abismo es, en cierto sentido, la muerte, y la muerte es vertiginosa, es fascinante. (...) para nosotros, que somos seres discontinuos, la muerte tiene el sentido de la continuidad del ser. (Bataille, 2013, p. 17).

Pensemos en la unión de los amantes en busca de la "pequeña muerte", de fundir sus individualidades en un todo indivisible. Se despojan de las ropas y entregan sus cuerpos desnudos a la marea sexual, donde el yo se pierde y se abandona en el fondo del océano carnal. O la pasión amorosa, que es el impulso hacia la unión imposible con la persona amada, esa desesperación por el otro que roza la locura y la muerte. En el encuentro con el otro la feliz e ilusoria continuidad va siempre precedida y orquestada por la mayor de las angustias; pasión y sufrimiento se confunden, pues la fusión completa nunca se produce y la posible pérdida del objeto amado se nos aparece como amenaza de muerte.

Este ansioso anhelo de fusión se fundamenta en aquella primera unión que vivenciamos y de la cual conservamos dolorosamente su fragancia a continuidad y máxima dicha: la díada madre e hijo de la cual nos habla el psicoanálisis (Lin-Ku y De Santiago, 2014), una simbiosis que forzosamente hay que romper para no caer exactamente en la muerte psíquica y la desaparición del sujeto 
(Tabares, 2005), construyendo en su lugar un yo individual y diferenciado, un territorio mental propio, una intimidad (Puertas, 2017).

De esta suerte, la violencia sexual y la violencia de la muerte se confunden, porque el impulso de amor, llevado hasta el extremo, es un impulso de muerte. Ambos son excesos y pertenecen al universo sádico, ambos desconciertan y sobrecogen el corazón humano. "La pasión nos susurra al oído: si poseyeras realmente al ser amado, tu corazón estrangulado por la soledad formaría un solo corazón con él o ella. La pasión insinúa el asesinato, el suicidio, la muerte" (Baigorria, 2003, p. 25).

No obstante, a pesar de bailar como funambulistas sobre la frontera entre la vida y la muerte, no es la muerte lo que se busca con tanta pasión, sino vivir más intensamente en el límite de morir.

Este deseo de zozobrar, que embarga íntimamente a cualquier ser humano, difiere no obstante del deseo de morir por su ambigüedad: es sin duda deseo de morir, pero, al mismo tiempo, es deseo de vivir, en los límites de lo posible y de lo imposible, con una intensidad cada vez mayor. Es el deseo de vivir dejando de vivir o de morir sin dejar de vivir, el deseo de un estado extremo (...). (Bataille, 2013, p. 245).

En el erotismo la vida discontinua no está condenada a desaparecer, tal como defiende Sade, sino que es puesta en entredicho, turbada, arrancada de toda tranquilidad y certeza. Empuja al hombre a hacerse preguntas acerca del ser, la nada, la discontinuidad de la existencia, la continuidad de la muerte.

Así pues, el erotismo corresponde a la práctica sexual del hombre cuando deja de ser rudimentaria para apelar a la experiencia interior del deseo, a la libertad y a lo sagrado, cuando abre un interrogante y posibilita que el ser se cuestione a sí mismo, porque el ser no tiene presencia real en nosotros más que sublevado.

\subsection{Erotismo y Belleza}

Todo objeto del erotismo posee un fondo común: la belleza. El deseo persigue la belleza, corretea como un niño emocionado tras un juguete bonito, y el juguete lo sabe. El objeto muestra al deseo su belleza y la belleza destaca su valor.
Las personas somos también posibles objetos de deseo, y como tales nos preocupa ensalzar la belleza de nuestro físico. Salvando las distancias entre las preferencias de los diferentes momentos y lugares, los diversos ideales de belleza no difieren demasiado entre ellos. Se trata siempre de alejar de la animalidad la imagen del cuerpo humano. Para ello el hombre ha ingeniado las más variadas y sutiles técnicas para desviar el cuerpo del cauce natural y moldearse bajo el canon establecido.

La belleza humana siempre exige alguna forma de mutilación. Se cubren algunas zonas y se descubren otras, se afeitan los pelos en algunos lugares y se dejan en otros. Siempre hay algo para ocultar, extirpar o arrancar. Uñas, vello, labios, pechos, cintura, pies y manos se ponen al servicio de instrumentos de disciplina: tijeras, hojas de acero, sujetadores, fajas, tacones, miriñaques, calzados de ajuste para impedir el crecimiento de los pies, como en la antigua China. Es inútil buscar 'naturaleza' alguna en el ideal de la belleza: sólo una lógica que va moldeando la realidad corporal para manejar las aproximaciones y fugas del deseo. (Baigorria, 2003, p. 102).

Por otro lado, este cuerpo explotado y castigado para suscitar el deseo en los demás busca potenciar aún más su hermosura y atractivo cubriéndose de ropas que ocultan y anuncian su anhelada desnudez. Es el júbilo del amante ir destapando centímetro a centímetro la piel de la compañera mas, paradójicamente, tras los vestidos son aquellas zonas recorridas por el vello, aquellas que son más animales, las más deseadas de todas.

Más aún, cuando al fin el cuerpo se ha quedado expuesto, puede desnudarse todavía más y mostrar sus secretos, pues posee varias aperturas que son promesas de placer y exceso. $\mathrm{Y}$ ante estos agujeros húmedos y oscuros buscamos ya no humanidad, sino bestialidad, porque el acto sexual nos conecta con la animalidad y con la fealdad. La belleza humana introduce de esta forma la oposición entre la humanidad más pura y la animalidad repelente de los órganos sexuales. Es el momento de ensuciar lo hermoso, del deleite de la profanación, porque "profanar la belleza es imprimir con violencia el rastro de un cruce bestial" (Baigorria, 2003, p. 102). 
La belleza es importante en primer lugar por el hecho de que la fealdad no puede ser mancillada, y que la esencia del erotismo es la fealdad. La humanidad significativa de la prohibición es transgredida en el erotismo. Es transgredida, profanada, mancillada. Cuanto mayor es la belleza, más profunda es la mancha. (Bataille, 2013, p. 151).

\subsection{Erotismo y Sacralidad}

Siendo el erotismo una experiencia subjetiva no puede ser estudiado como un objeto exterior al hombre, como si de una cobaya en un laboratorio se tratase. Sólo puede ser comprendido desde dentro, al igual que la religión. El erotismo es sagrado, pero no en el sentido de la búsqueda de Dios, sino como el anhelo de un ser más allá del mundo inmediato y finito, el deseo de romper con la soledad del ser aislado para alcanzar el sentimiento de totalidad. En definitiva, el erotismo es abrir el cuerpo a lo infinito, es el movimiento que fluye de la discontinuidad a la continuidad del ser.

Y la continuidad del ser no es otra que la muerte, aquella que pone fin a la existencia de los seres individuales, aquella que disuelve todos los seres en las aguas de la eternidad.

Lo que despierta el sentimiento de lo sagrado es el horror. (...) Lo que más horror nos da es la muerte; y en el sentimiento de lo sagrado, la existencia es vecina de la muerte, como si dentro de un sueño, el contenido de un ataúd nos arrastrara hacia él. (Bataille, citado en Baigorria, 2003, p. 108).

El erotismo es por tanto criminal porque "el terreno del erotismo es esencialmente el terreno de la violencia, de la violación" (Bataille, 2013, p. 21). Por ello es también ambivalente: reúne vida y muerte bajo la misma experiencia y ser consciente de ello perturba terriblemente al ser humano.

Pulsión de vida y pulsión de muerte necesitan el uno del otro como la noche y el día, o el cielo y el infierno. Como asumir todas las consecuencias de este vínculo irrompible empujaría al alma hacia unos niveles de angustia insoportables, el hombre se escuda tras corazas y murallas en un intento de contener la locura y equilibrar la psique, aunque para ello tenga que caer, en última instancia, en la perversión (Yakeley, 2018).

\subsection{Deseo y Falta}

No se puede hablar de erotismo sin hablar de deseo, esa fuerza interna que nos impulsa a aprehender, a superar, a construir, a buscar al otro,... Esa fuerza que no es posible sin la ausencia, pues es ante la falta cuando surge el deseo de colmarla. Ya lo decía Freud (1938): "para que el deseo sea posible el sujeto ha de asumir su propia castración simbólica o, en otras palabras, dejar de ser 'su majestad el niño' y aceptar la herida narcisista" (pp. 3415-3416). Sólo así, con su finitud, sus agujeros y sus límites el ser humano saldrá del ensimismamiento y se entregará a la cultura y al otro (Chasseguet-Smirgel, 1998). Si por el contrario se acomoda en su trono de omnipotencia quedará atrapado en ese plus de goce mortal (Rivera, 2010).

Lo que está al acecho por debajo de esa actitud narcisista es, sin embargo, la pulsión de muerte freudiana, una especie de tenacidad "que no muere" ya denunciada por Kant como un exceso violento que está ausente en los animales, que es la razón de que sólo los humanos necesiten ser educados por medio de la disciplina. La Ley simbólica no domestica y regula la naturaleza, sino que, precisamente, se aplica ella misma a un exceso innatural. (Žižek, 2006, p. 106).

Por supuesto, esta falta es incolmable, primero porque el objeto perdido está perdido para siempre (la ilusión de completud con la imagen materna) (Vanier, 2017), y segundo porque la satisfacción del deseo conllevaría la muerte del sujeto. Colmar el deseo es lo mismo que agotar el deseo, puesto que ya no habría sueños que cumplir ni metas que perseguir: es el estado de la plenitud donde no cabe absolutamente nada.

Los deseos nunca son enteramente satisfechos, y mediante este fiasco inevitable, que representa una muerte pasajera y temporal, el deseo testimonia su eterna juventud y nutre su vitalidad. Triunfa porque cuando pierde salva al mismo tiempo su sucesión y evita capitular. (Colina, 2006, pp. 14-15).

Así, el deseo fluye como una montaña rusa, con fuertes subidas y descensos abruptos para volver a renacer, crecer y de nuevo desilusionarse y morir. Se trata de una fuerza pulsional que salta vertiginosamente de objeto en objeto, condenada 
eternamente a la frustración, mas también a vivir, pues si bien el deseo empuja siempre hacia adelante, también sabe cambiar de rumbo a tiempo si se encuentra cara a cara con la muerte. Pero mientras la amenaza no aparezca más que como un mero aviso, el deseo seguirá coqueteando con el abismo en busca de una cada vez mayor excitación y entretenimiento. En efecto, es en esa fina línea que separa vida y muerte donde encontramos los más altos placeres, donde nos encontramos con nuestro ser.

La constante decepción que nos brinda el deseo no parece tan mala compañera de viaje cuando se la compara con su alternativa, y es que si nos dejáramos llevar por nuestras pulsiones acabaríamos consumiéndonos por nuestra exuberante sexualidad y sangrienta agresividad, antípoda la una de la otra pero a la vez inseparables.

La sexualidad y la muerte sólo son los momentos agudos de una fiesta que la naturaleza celebra con la inagotable multitud de los seres; y ahí sexualidad y muerte tienen el sentido del ilimitado despilfarro al que procede la naturaleza, en un sentido contrario al deseo de durar propio de cada ser. (Bataille, 2013, p. 273).

En suma, el deseo y la insatisfacción se entrelazan para toda la eternidad en beneficio de la vida. No resulta extraño, entonces, que la propia cultura ponga frenos a sus pasiones, siempre bajo la intuición de que el recto camino de la virtud no es para nada el más divertido.

\subsection{Prohibición y Transgresión}

El ser humano no acepta la naturaleza tal cual. Modifica a conveniencia el mundo exterior y se educa a sí mismo enjaulando a su animal interior. La sociedad se funda así sobre sus prohibiciones (Caniato, Cesnik \& Rodrigues, 2012), sin las cuales las energías individuales se desbordarían y harían insostenible la convivencia de los unos con los otros y consigo mismos. Así pues, le ponemos cadenas a nuestros impulsos y nos vestimos de moderación. De esta necesidad de orden nace el trabajo, tarea organizada mediante la cual renunciamos a la satisfacción inmediata a cambio de un placer tímido y postergado.

El animal humano transforma el principio de placer en principio de realidad: puede distinguir entre satisfacción inmediata y retardada, entre el goce y su restricción, entre el trabajo y el juego. La razón promete un beneficio ulterior a cambio de la renuncia al placer sin límites. Uno podría ceder al arrebato natural, a la tentación de saciar ya sus deseos, al goce impetuoso de los sentidos. Pero no lo hace. Se trata de una autorrenuncia; si bien, desde que el hombre vive en sociedad, es ante todo una restricción colectiva: la comunidad asume la paradoja de restringir y coartar la vida para que la vida no cese. (Baigorria, 2003, p. 29).

Si bien la instauración del trabajo posibilitó la convivencia entre los seres humanos, también nos condenó a la ignorancia de una parte de nosotros mismos al dejar excluida de la vida social la sexualidad y la muerte, ambas grandes perturbaciones para el mundo laboral, pero finalmente realidades ineludibles de la existencia humana sin las cuales la vida no tendría sentido.

En la medida en que el hombre se definió mediante el trabajo y la conciencia, tuvo no sólo que moderar, sino que ignorar y a veces maldecir en sí el exceso sexual. En un sentido, este desconocimiento ha apartado al hombre, si no de la conciencia de los objetos, al menos de la conciencia de sí mismo. Lo ha encaminado al mismo tiempo hacia el conocimiento del mundo y hacia la ignorancia de sí. Pero si trabajando no se hubiera vuelto primero consciente, no habría en absoluto conocimiento: estaríamos aún en la noche animal. (Bataille, 2013, p. 167).

En efecto, todos los individuos inmersos en la misma cultura se sacrifican por el bien común y renuncian a una parte de sí para estar en consonancia con los demás. Dicha situación conlleva cierta paradoja: lo vetado es también lo más deseado por la humanidad; si no fuera así no habría necesidad de dictar prohibición alguna. Por ello la transgresión de la norma no sólo conduce a la culpa, sino también al placer. Angustia y goce se presentan irremediablemente ligados para la instauración de los límites y la posibilidad de jugar con ellos (Alberti \& Martinho, 2013).

Pero experimentamos, en el momento de la transgresión, la angustia sin la cual no existiría lo prohibido: es la experiencia del pecado. La experiencia conduce a la transgresión acabada, a la transgresión lograda que, manteniendo lo prohibido como tal, lo mantiene 
para gozar de él. La experiencia interior del erotismo requiere de quien la realiza una sensibilidad no menor a la angustia que funda lo prohibido, que al deseo que lleva a infringir la prohibición. (Alberti \& Martinho, 2013, p. 43).

El terreno del erotismo es precisamente el de la transgresión de la prohibición (Briole, 2004), y precisamente por ello la satisfacción del deseo no es siempre de nuestro interés. Recordemos que al deseo le gusta fluir en la penumbra; a la luz los hechos pierden su encanto.

La prohibición da un sentido que en sí misma la acción prohibida no tenía. Lo prohibido compromete en la transgresión, sin la cual la acción no tendría el resplandor de maldad que seduce (...) Es la transgresión de lo prohibido la que hechiza (...). (Bataille, 1981, p. 47).

Así pues, a pesar de ser seres racionales, sobrevive en nosotros un fondo de violencia (Ruiz, Ruiz \& Fernández-Baca, 2007) que sólo puede ser reducido parcialmente, que no es otra que la tentación imperecedera de violar la ley. Tanto si lo que está en cuestión es la sexualidad como si lo es la muerte, lo que está siempre en el punto de mira de la prohibición es la violencia, la violencia que atemoriza, pero que también fascina (Bataille, 2013, p. 52).

Resulta obvio que el erotismo se relacione a menudo con la idea del Mal pues, al contrario que el trabajo, no produce, gasta. Pero es que el erotismo apela a la sinrazón, es exceso y anhelo de traspasar los límites, y los traspasará siempre que los vacíos legales de la sociedad se lo permitan.

Sin embargo, ni el trabajo nos absorbe íntegramente ni la razón es siempre obedecida. Aun en medio de nuestras actividades más racionales, siempre hay un afuera de la razón, que está al acecho, en las sombras, plantado como una amenaza, aprovechando cada grieta del orden social para irrumpir con toda su voluntad de desorden. (Baigorria, 2003, p. 29).

El monstruo espera ansioso para salir corriendo de la jaula a la mínima oportunidad. "En la guerra hemos podido comprobar cuán tenue es la capa de civilización que recubre al hombre primitivo, cuán grande es la crueldad humana, cómo se desahoga en cuanto se presenta la menor ocasión" (Stekel, 1954, p. 826).

De hecho, el ser humano ha inventado, en todos los tiempos y lugares, excepciones donde las líneas se difuminan, un tiempo de ocio que se contrapone al tiempo de trabajo, un juego contrario al principio de conservación donde el gasto se impone. Curiosamente, hasta la transgresión está regulada por el cuerpo social; parece que nada escapa de su atenta mirada. Muestra de ello es la guerra, paréntesis temporal donde la aniquilación es permitida e incluso exigida o, dentro del ámbito que nos concierne ahora mismo, las orgías dionisíacas o la prostitución ritual, donde el tabú sexual se viola "religiosamente". Y es que rechazar la violencia del impulso natural no significa romper del todo con nuestra animalidad, sino acordar un pacto con nuestras bestias.

Por tanto, el Mal no es la transgresión en sí, sino la transgresión condenada: el pecado. Lo demás está permitido. Podemos aflojar los grilletes, pero con el suficiente cuidado de no perder de vista al monstruo, o se escapará. En este punto se vuelve comprensible la necesidad de definir ya no sólo las normas, sino también las condiciones de su transgresión.

A menudo, en sí misma, la transgresión de lo prohibido no está menos sujeta a reglas que la prohibición. No se trata de libertad. En tal momento y hasta ese punto, esto es posible: éste es el sentido de la transgresión. Ahora bien, una primera licencia puede desencadenar el impulso ilimitado a la violencia. No se han levantado simplemente las barreras; incluso puede ser necesario, en el momento de la transgresión, afirmar su solidez. En la transgresión se suele poner un cuidado máximo en seguir las reglas; pues es más difícil limitar un tumulto una vez comenzado. (Bataille, 2013, p. 88).

De manera tal que la ley no se establece y mucho menos se cumple en forma rigurosa. Aparte de los paréntesis acordados, las expresiones moderadas son toleradas mientras tengan lugar en el espacio de la intimidad y el secreto pero, de modo hipócrita, todo exceso fuera de estos márgenes cae bajo la lápida de la perversión. 


\section{EL PENSAMIENTO DE SADE}

\subsection{Un Discurso Racional de lo} Irracional

En apariencia el discurso de Sade es extremadamente racional. Analiza y argumenta escrupulosamente bajo la luz de la evidencia y es frecuente el uso de sistemas de lógica. Vuelve una y otra vez, incansable, sobre los mismos asuntos, para observarlos con mira microscópica desde todos los ángulos posibles, respondiendo y resolviendo toda objeción que aparece. No hay traba en el pensamiento que lo haga titubear ni enigma que ponga fin a su paciencia. Su lenguaje es abundante, pero también directo, conciso y firme.

No obstante, bajo toda esta intensa racionalización nos encontramos con un trasfondo de lo más irracional. No se sabe con certeza de dónde parte su pensamiento ni hacia dónde va. Es un pensamiento que se reconstruye continuamente, sin inicio ni final. Es el lenguaje de lo real.

Lo que Sade escribo, digo "escribe" y no "describe", es el fantasma, y por ende escribe lo real, sin realismo. La empresa de Sade consiste en llevar al paroxismo la transgresión del enunciado de las reglas morales, transgresión en el lenguaje mismo. (Bedouelle, 2006, p. 4).

Su literatura, teatralización de su mente, emana en todo momento cierta incoherencia y confusión. Sus personajes se entregan en nombre de la razón a elaborados desarrollos teóricos que no parecen tener culminación pero sí muchas contradicciones. La incongruencia palpable de su pensamiento se debe quizá a su tentativa de otorgar voz a la violencia cuando la violencia es en sí silenciosa.

Dije que la violencia es muda. Pero el hombre castigado por un motivo que considera injusto no puede aceptar callarse. Guardar silencio sería como aprobar la pena impuesta. En su impotencia, muchos hombres se contentan con un desprecio mezclado de odio. El marqués de Sade, sublevado en su prisión, tuvo que dejar que en él hablara la rebeldía: habló, lo que la violencia por sí sola no hace. $\mathrm{Al}$ rebelarse, tenía que defenderse, o mejor atacar, llevando el combate al terreno del hombre moral, al que pertenece el lenguaje. El lenguaje fundamenta el castigo, pero sólo el lenguaje pone en tela de juicio este fundamento. (...)
Por esta vía se enfrentaría al universo, a la naturaleza, a cuanto se oponía a la soberanía de sus pasiones. (Bataille, 2013, pp. 196-197).

Llegamos de esta forma a una violencia que tiene la serenidad de la razón, una violencia que procura agotar toda duda e instaurar la convicción a través de una lógica difícilmente aceptable por la sociedad. "No solamente la anarquía de Sade es inconmensurable hasta con las magnitudes astronómicas; su propia concepción del hombre haría estallar la bóveda de todos los templos" (Heine, 1980, p. 17).

Racional o irracional, a través de sus obras el marqués de Sade se coloca un paso por delante y consigue enfrentarse a una verdad tan sombría y enloquecedora que apenas nadie se atreve siquiera a rozar. Él avanza allí donde otros nos detenemos frente el vértigo de una nueva libertad de pensamiento que no conoce límites. Mientras otros damos tímidos rodeos y pasos en falso él se sumerge de lleno en el pletórico océano de la perversión.

\begin{abstract}
Hoy, que el humanismo es usado para encubrir la inhumanidad de los hombres, que los derechos del hombre sirven para despreciar el derecho de gentes, que la razón finalmente se agota sin reconocer los monstruos que ha engendrado, ¿no estamos obligados a preguntarnos, mucho tiempo después de Sade, lo que este sigue sosteniendo? (Le Brun, 2008, p. 10).
\end{abstract}

Logra hacer consciente lo inconsciente, desterrar la bestia pulsional para integrarla con la tibia razón humana. De este modo, ante el legado sadiano ya nadie jamás podrá ignorar la maldad latente en todo hombre. Su enseñanza prepara el camino para el entendimiento y la aceptación de los más escandalosos impulsos criminales que existen en el corazón humano.

Quería sublevar la conciencia, hubiera querido también esclarecerla, pero no pudo a un tiempo sublevarla y esclarecerla. Sólo hoy entendemos que, sin la crueldad de Sade, no hubiéramos alcanzado tan fácilmente este campo antaño inaccesible donde se disimulaban las más penosas verdades. (Bataille, 2013, p. 202). 
En efecto, lo que Sade quiere es justamente enfrentar la conciencia con aquello que con tanto fervor oculta, que es, a sus ojos, el más poderoso medio de provocar placer.

\subsection{Evolución del Pensamiento Sadiano}

El pensamiento de Sade va evolucionando a lo largo de un movimiento dialéctico cuyo punto central es siempre el cuestionamiento de toda construcción social, ya sea política, moral, religiosa o de otra índole.

Respecto al poder creador de la humanidad, en un primer momento defiende la idea de un Dios infernal que hace el Mal a la humanidad y que pide la misma moneda de cambio: exige el Mal. El libertino ha de desprenderse del engaño social de la supuesta virtud para aceptar a Dios con todos sus pecados y a su vez admitirse a sí mismo como vicioso, como obra de ese ser supremo de la maldad.

Si las desdichas que me agobian desde el día de mi nacimiento hasta el de mi muerte prueban su despreocupación hacía mí, puedo muy bien equivocarme acerca de lo que llamo mal. Lo que caracterizo así con respecto a mí es verosímilmente un gran bien para el ser que me puso en el mundo: y si recibo el mal de los demás, gozo del derecho de devolvérselo y de la facilidad de hacerlo el primero: a partir de aquí, el mal es un bien para mí como lo es para el autor de mis días con respecto a mi existencia: soy feliz por el mal que hago a los demás, como Dios es feliz por el que me hace... (Sade, citado en Klossowski, 2005, p. 80).

En un segundo momento, Sade arremete contra la ley divina, entendida como invención humana que atenta contra la única ley válida: la de la Naturaleza. El libertino sadiano representa aquí un estado de espíritu intermedio entre el del hombre social y el del hombre ateo de la Naturaleza. No hay crimen posible porque el crimen es el espíritu de la naturaleza. Ella nos otorga tanto vicios como virtudes, y como criaturas suyas hemos de hacer uso de los dos.

Amigo mío, mi alma es lo que ha querido la naturaleza que sea, es decir, el producto de órganos que ella se ha complacido en brindarme, conforme a sus designios y necesidades; y como tiene idéntica necesidad de vicios y de virtudes, cuando ha deseado llevarme hacia los primeros, lo ha hecho, cuando ha querido las segundas, me ha inspirado los deseos consiguientes, y me he entregado a ellas sin reparos. En esas leyes de la naturaleza, que responden sólo a sus deseos y a sus necesidades, debes buscar la causa única de la inconsecuencia humana. (Sade, 1997, pp. 28-29).

De esta forma, Sade se enfrenta a la Naturaleza violenta y destructora de sus creaciones con la misma pasión e ira con que se enfrentó anteriormente a Dios, o incluso más. Le reprocha haberle creado a su imagen y semejanza, convirtiéndolo en un ser totalmente cruel y hostil que disfruta haciéndole el Mal a sus semejantes.

Pues bien, ¿existe un ser más despreciable y odioso que el que me dio la vida sólo para hacerme encontrar placer en todo lo que daña a mis semejantes? ¡Y qué! apenas nací... apenas salí de la cuna de ese monstruo, me arrastra a los mismos horrores que los que la deleitan a ella. Aquí ya no se trata de corrupción... es inclinación, es tendencia. Su mano bárbara sólo sabe amasar el mal: así que el mal la divierte: ¡y yo debería amar a semejante madre! No, la imitaré, pero detestándola, la copiaré, si así lo quiere, pero sólo será maldiciéndola... (Sade, como se citó en Klossowski, 2005, pp. 85-86).

En este punto Sade desvincula al hombre de la Naturaleza. La Naturaleza crea al ser humano con sus propias leyes humanas, y desde ese momento deja de tener control sobre él. En otras palabras, la naturaleza del hombre (naturaleza segunda) es distinta a la Naturaleza original (naturaleza primera), y por tanto las leyes que le son propias al ser humano no le son necesarias a la Naturaleza. Ya puede la humanidad duplicarse o extinguirse que a la Naturaleza le es indiferente, ya que existe independientemente de sus criaturas, existe sin principio ni fin, sin causa ni finalidad. Es más, piensa el marqués que multiplicándose el hombre atenta contra los fenómenos naturales, haciéndole competencia a la Naturaleza y a su poder de creación. Siendo así, destruyéndose a sí mismo la estaría incluso beneficiando y ayudando en sus propósitos.

Esos crímenes que nuestras leyes castigan con tanto rigor, esos crímenes que suponemos 
son el mayor ultraje que podamos hacerle, resulta que no sólo, como puedes ver, no le hacen ni pueden hacerle daño alguno, sino que son, de algún modo, útiles a sus fines; y esos crímenes que imita tan a menudo, podemos estar seguros de que lo hace sólo por deseo de aniquilar totalmente las criaturas que ella impulsa, a fin de poder gozar de esa facultad suya de dar impulso a otras. El mayor criminal de la tierra, el asesino más abominable, el más feroz y bárbaro es apenas un órgano de sus leyes... un móvil de sus voluntades y el agente más confiable de sus caprichos. (Sade, 1997, pp. 151-152).

El pensamiento de Sade desemboca así en un principio básico: el de la liquidación de la especie humana. La idea del hombre cae en el infinito. Es la moral del movimiento perpetuo de la Naturaleza, donde todas las criaturas, incluidos los seres humanos, representan las fases cambiantes de ese movimiento eterno. La muerte y la descomposición de los cuerpos no son más que la puesta en marcha de la circulación de las sustancias necesarias para la incesante llegada al mundo de nuevos seres. La vida es sólo un instante, una transición.

Nada nace, nada perece esencialmente, todo es acción y reacción de la materia. Es el subir y bajar incesante de las olas del mar, en cuya masa de aguas no se produce pérdida ni incremento. Es un movimiento perpetuo que ha sido y será siempre, y sin saberlo somos sus principales agentes, debido a nuestros vicios y virtudes. Es una variación infinita: millares de porciones de diferentes materias bajo toda suerte de formas se destruyen y vuelven a aparecer bajo otras formas, para de nuevo perderse y aparecer. (Sade, 1997, p. 157).

Al final, tras hacer frente a todo poder superior posible, el héroe de Sade se alza como gran vencedor. Destruye al hombre, a Dios y a la Naturaleza para coronar la idea del Mal en estado puro.

El hombre integral, que se afirma completamente, es insensible. Ha comenzado por destruirse él mismo, en tanto que hombre, después en tanto que Dios, después en tanto que naturaleza, y así se ha convertido en el único. Ahora todo lo puede, pues la negación en él ha acabado con todo. (Blanchot, 1990, p. 23).

\subsection{De una Religión del Mal al Ateísmo Íntegro}

En este examen sadista de las construcciones sociales la religión no iba a ser una excepción.

Acorde a su pensamiento, Sade aborrece a todos aquellos que agachan la cabeza ante un Dios que no existe. Frente a los enigmas irresolubles de la Naturaleza el ser humano inventó un ser todopoderoso y omnipotente, origen de todo lo inexplicable. Con esta figura al frente la humanidad pudo calmar su angustia ante lo desconocido y garantizar un mundo ilusorio donde la paz y la justicia terminan siempre por instaurarse sobre los horrores y las penas. Sin embargo, poco a poco, de esta comodidad que otorgaba el tener al fin respuesta para todo surgieron también la adoración, la sumisión y finalmente el temor.

Físicos crédulos y entusiastas, copien tratados de botánica para probarnos la existencia de Dios; den como Fénelon un detalle minucioso de las partes del hombre; arrójense por los aires para admirar el curso de los astros; maravíllense ante las mariposas, los insectos, los pólipos, los átomos organizados, en los que creen hallar la grandeza de su vano Dios: todas esas cosas, por más que ustedes lo digan, nunca demostrarán la existencia de ese ser absurdo e imaginario; solamente probarán que ustedes no tienen las ideas adecuadas sobre la inmensa variedad de materias y de efectos que pueden producir unas combinaciones diversificadas hasta lo infinito, cuyo conjunto es el universo. (Sade, como se citó en Le Brun, 2008, pp. 72-73).

La idea de Dios es para el marqués, de alguna forma, el gran pecado del hombre, la prueba irrefutable de su insignificancia. Al aceptar la anulación frente a Dios se justifica automáticamente el crimen, pues frente un dios todopoderoso el hombre corriente es reducido a la nada. La humanidad ha cavado su propia tumba al convertirse en creyente.

Pero ser ateo tampoco rescata al hombre de las ataduras de Dios y de la insignificancia. Para Sade, el ateísmo racional es en realidad un monoteísmo invertido. La relación negativa con Dios no es más que una forma indirecta de aceptar su existencia, pues quien profesa el ateísmo racional 
tiene por finalidad, a través de sus ofensas y delitos, provocar que el Dios ausente manifieste su existencia. El ateo actúa movido por el resentimiento y la resignación, y un verdadero libertino sadiano ha de obrar bajo la idea del Mal y por ningún interés más. Y es que no hay para el hombre peor enemigo que Dios. El verdadero ateísmo es aquél que supone el fin de la razón establecida: el ateísmo íntegro. Sade propone la primacía de lo imaginario sobre lo racional, pues la razón viene impuesta desde arriba, por los organismos de poder.

Paradójicamente, la necesidad de transgresión contradice el ateísmo íntegro de Sade porque su fin último, su sueño, su utopía del Mal, se cumpliría precisamente si toda la humanidad se volviera perversa, o lo que es lo mismo, si ya no hubiera monstruos. "En una palabra: hay que hacer que el mal reine en el mundo para que se destruya a sí mismo y que el espíritu de Sade encuentre al fin su paz" (Klossowski, 2005, p. 53). Pero como tal realidad es imposible, el ateísmo íntegro sólo puede tener lugar dentro de las condiciones del sadismo, pues son las normas y las instituciones existentes las que estructuran la perversión y la posibilitan. Como muestra de ello Sade introduce a sus personajes en la vida cotidiana como símbolo de que la contrageneralidad existe de forma implícita dentro de la generalidad.

Por todo lo anterior Sade no concibe la perversión en el sentido patológico; sólo existe en el sentido moral, en el sentido de la liberación del hombre de las garras de la cultura. La perversión implica por ello la suspensión de las funciones vitales y sociales, ir contra natura y contra la sociedad. Persigue la expropiación del cuerpo propio y del cuerpo del otro puesto que representan órganos sociales inmersos en el lenguaje de las instituciones y el poder opresor. Liberarse del cuerpo es liberarse de la ley, y para conseguirlo el cuerpo subjetivo ha de ir desapareciendo en la medida en que la voz impersonal del Mal se alce en su lugar para romper con toda ilusión y superficialidad humanas. Sade invita a la humanidad a encontrarse con su inhumanidad.

(...) Sade ya ha pasado del otro lado del orden humano, allí donde lo inhumano se desprende de la silueta humana, donde el objeto se libera del vestigio del sujeto, donde lo que somos se enfrenta a lo que creemos ser. A partir de entonces, para él se trata de salir al encuentro de nuestra inhumanidad, de la inhumanidad que sospechamos en el fondo de nosotros mismos y cuyo descubrimiento nos petrifica. Escandalosa piedra en el lugar del corazón, insoslayable piedra de escándalo, irrompible piedra de toque con que está construido el castillo de Silling ${ }^{1}$. (Le Brun, 1998, p. 55).

\subsection{Nihilismo Moral}

Se desprende de lo expuesto hasta ahora que cada cual debe hacer lo que le plazca y cuando le plazca, y no lo impuesto por la soberanía popular. La voluntad general se adjudica a sí misma todo derecho y poder, condena y desplaza a todo aquél que no se comporte bajo su normativa e ideología, y el ser humano aun se deja engañar, cayendo ingenuo en la trampa social.

La voluntad general reposa de este modo en ese malentendido, inherente a la ética, de que el individuo no podría por sí solo representar a la especie de una manera intrínseca; en el seno de esa voluntad general sólo cuenta aquel que, al reducirse él mismo a una reivindicación determinada, logra identificarse con otros individuos reducidos como él a esa reivindicación. La lógica ordena entonces retirar el derecho de existir a aquel que, al quedar fuera de la especie, es necesariamente un monstruo. (Klossowski, 2005, p. 131).

Sin Dios ni institución, sin ninguna naturaleza superior, el hombre puede ya, y debe, moverse por su propio interés. El más absoluto egoísmo será de ahora en adelante su única guía. Respetar al prójimo es absurdo, pues sólo conduce a la innecesaria subordinación de los unos a los otros, de igual manera que entablar lazos entre individuos orienta al hombre a coartar su propia emancipación.

La verdad del erotismo es la traición. (...) La solidaridad hacia todos los demás impide que el hombre tenga una actitud soberana. El respeto del hombre por el hombre nos introduce en un ciclo de servidumbre donde ya no tenemos sino momentos de subordinación, donde finalmente faltamos al respeto que es el fundamento de nuestra actitud, puesto que en general privamos al hombre de sus momentos de soberanía. (Bataille, 2013, pp. 176-177). 
Para Sade todas las personas somos iguales por naturaleza, ninguna vale más que otra y todas somos intercambiables. La naturaleza nos hace nacer solos y bien podríamos crecer y subsistir solos porque no existe relación natural alguna entre un hombre y otro; somos nosotros quienes nos creamos la necesidad de establecer vínculos inútiles y nos atamos a ellos como esclavos. Por tanto, toda persona tiene pleno derecho de no sacrificarse por la conservación de los otros, incluso si su felicidad conlleva la ruina de los demás. Nadie ha de privarse de satisfacer uno sólo de sus deseos por un otro que nada tiene que ver con él.

Tengamos la fuerza de renunciar a lo que esperamos de los demás y nuestros deberes hacia ellos terminarán en seguida. ¿Qué son, pregunto, todas las criaturas de la tierra frente a uno solo de nuestros deseos? ¿Y por qué razón me privaría del más insignificante de esos deseos para complacer a una criatura que no es nada para mí y que en nada me interesa...? (Sade, como se citó en Klossowski, 2005, pp. 96-97).

Así pues, la filosofía de Sade es la filosofía del interés y del placer, cuyo principio fundamental es que nos entreguemos a todos aquellos que nos desean y tomar a todos aquellos a quienes deseamos.

El mayor dolor de los demás cuenta siempre menos que mi placer. Qué importa, si yo debo comprar el más débil regocijo a cambio de un conjunto de desastres, pues el goce me halaga, está en mí, pero el efecto del crimen no me alcanza, está fuera de mí. (Blanchot, 1990, p. 3).

Rechazado todo cuanto nos une los unos con los otros, se suprime no solamente la conciencia del prójimo, sino también la conciencia de sí mismo.

De ello resulta que si el otro no es nada para mí, no solamente no soy ya nada para él, sino nada tampoco en relación con mi propia conciencia y todavía es preciso saber que esa conciencia siga siendo mía. Pues si rompo con el prójimo en el plano moral, habré roto en el plano de la existencia misma con mi propiedad: a cada instante puedo caer a merced del otro, que haría la misma declaración. (Klossowski, 2005, p. 97).
La última consecuencia del hilo de su pensamiento es por tanto el nihilismo moral, la supresión de la conciencia de sí mismo y del prójimo en el plano de los actos. Sade no se conforma con cuestionar la existencia de un Dios, garantía del yo responsable, sino que interroga también el principio normativo de la individuación.

\subsection{Poder y Crimen}

En un mundo de igualdad el poder no está predestinado en manos de nadie; ha de conquistarse. Por supuesto, hay quienes tienen facilidad desde la cuna al nacer en familias con posiciones privilegiadas, pero eso no significa que estos individuos no puedan caer y que los que nacen en la miseria no puedan emerger. Y para alcanzar el poder hay que empezar por superar los prejuicios que encadenan el mundo: hay que cometer el crimen.

El libertino sadiano no teme al castigo divino porque es ateo; no existe para él la amenaza de Dios, sólo su egoísmo y placer. Se eleva como hombre soberano sobre las cabezas de los demás, sin posibilidad alguna de ser víctima, pues al hombre vinculado al Mal nunca puede sucederle algo malo. "Para Sade, el hombre soberano es inaccesible al Mal porque nadie puede hacerle mal; es el hombre de todas las pasiones y sus pasiones se complacen en todo" (Blanchot, 1990, p. 10). Autor o receptor de los males, siempre goza; sólo importa que la violencia sea tan extrema que burle todos los límites posibles. Violar, torturar, amputar, desollar,... Ser violado, ser torturado, ser amputado, ser desollado,... El soberano absoluto ha de probarlo todo para no estar subordinado a nada. Padecer la desgracia y vivenciar el placer no son ya contrarios.

Así es el mundo: algunos seres que se han elevado a lo más alto y alrededor de ellos, infinitamente, una polvareda sin nombre y sin número de individuos que no tienen ni derecho ni poder. Veamos en qué se convierte la regla del egoísmo absoluto. Yo hago lo que me place, dice el héroe de Sade, sólo conozco mi placer y, para asegurarlo, torturo y mato. Vosotros me amenazáis con una suerte parecida para el día en que encontraré alguien cuya felicidad será torturarme y matarme. Pero yo he adquirido precisamente el poder para elevarme por encima de esta amenaza. (Blanchot, 1990, p. 6). 
Leyendo las novelas de Sade cabe pensar que sus héroes se alían entre ellos y mantienen relaciones entre iguales, pero entre los cómplices siempre acecha silenciosa la traición y se desvela que su acuerdo obedece a una suerte de reglamento entre compañeros de juego con demasiado anhelo por hacer trampas. El juramento establecido entre ellos no es más que una excusa para tener el placer de romperlo, para multiplicar las posibilidades del goce.

Ni tan siquiera depende el libertino sadiano de sus súbditos como lo hace un rey; su poder no es limitado por lealtad ninguna. No obstante, el héroe sadiano, "libre ante los demás, no deja de ser víctima de su propia soberanía" (Bataille, 2013 , p. 180). Se encuentra esclavizado por la más absoluta voluptuosidad y ya nunca más podrá conformarse con goces menores. Sade nos habla de una violencia tan cruel que para alcanzar su culminación no importa ya el placer personal; sólo importa el crimen. Así, aunque la negación del otro conduzca aparentemente a la afirmación del sí mismo, en realidad este carácter ilimitado lleva al extremo de lo posible, más allá del goce subjetivo. Es el imperio del egoísmo impersonal donde no hay cabida para el yo individual.

En consecuencia, el ateísmo de Sade es la religión de la monstruosidad. El rechazo de la existencia de Dios no trae consigo el gozo para el ser humano, sino la tragedia. Ni siquiera defiende Sade la soberanía del hombre, sino la destrucción de la humanidad a través de la desintegración de las normas de la razón popular.

\subsection{Destrucción y Negación}

En el pensamiento sadista se trata de negar al prójimo para descubrir la verdadera cara del erotismo. La sexualidad del hombre íntegro no complementa la sexualidad del prójimo, sino que se contrapone a ella e incluso la anula. Sólo de esta forma el erotismo obedece a su naturaleza violenta y mortífera.

La satisfacción sexual acorde al deseo de todos no es la que Sade puede desear para los fines de sus personajes soñados. La sexualidad en la que piensa se contrapone incluso a los deseos de los demás (de casi todos los demás), que no pueden ser sus protagonistas, sino sus víctimas. Sade propugna la unicidad de sus héroes. La negación de los otros protagonistas es, según él, la pieza fundamental del sistema. A sus ojos, el erotismo, si lleva al acuerdo, desmiente el movimiento de violencia y de muerte que en principio es. (...) Sólo la voracidad de un perro feroz llevaría a cabo la furia de aquel al que nada limitase. (Bataille, 2013, p. 173).

Sin embargo, no sólo la unión sexual une a las personas; también lo hace la muerte. Por ello el héroe de Sade ha de matar sin horizontes, porque cuando las víctimas se cuentan por millares, el hombre se libera de toda relación que pueda encadenarlo a otros seres. Se vuelve amo y señor de todo.

El criminal se une posiblemente de manera indisoluble con aquel a quien asesina. Pero el libertino que, inmolando a su víctima no resiente sino la necesidad de sacrificar a otras miles, parece extrañamente libre de toda unión con ella. A sus ojos, ella no existe en sí misma, no es un ser distinto, sino un simple elemento, indefinidamente sustituible, en una inmensa ecuación erótica. (Blanchot, 1990, p. 14).

Como hombre soberano Sade todo lo quiere destruir, "no hay nada respetado que él no ridiculice, nada puro que no mancille, nada amable que no colme de horrores" (Bataille, 2000, p. 173). Los cuerpos se entrelazan, se separan, se funden y se deshacen al igual que las palabras del discurso sadiano. Todo es llevado a su ebullición y evaporación una y otra vez, sin descanso, ad infinitum.

$\mathrm{Y}$ es que la esencia del pensamiento de Sade es destruirlo absolutamente todo, inclusive a sí mismo, puesto que no se limita a refutar en sus escritos la existencia de Dios, sino que piensa, actúa, vive y muere en consecuencia.

Al excluirse de la humanidad, Sade no tuvo en su larga vida más que una ocupación que decididamente le interesó: enumerar hasta el agotamiento las posibilidades de destruir seres humanos, destruirlas y gozar con el pensamiento de su muerte y sus sufrimientos. (...) Sólo la enumeración interminable, aburrida, tenía la virtud de extender ante él el vacío, el desierto, al que aspiraba su rabia. (Bataille, 2000, p. 163).

Es la destrucción de los objetos lo que despierta la vida en el personaje sadista, hasta el 
punto de que su aniquilación no admite siquiera su existencia anterior, sino que desde el inicio son considerados objetos nulos. El hombre soberano ha de perseguir el desbordamiento de la negación y avergonzarse de los crímenes pequeños y escasos.

Esta concepción recuerda al deseo freudiano (Freud, 1905), deseo eternamente insatisfecho que en todo momento quiere para sí lo que no tiene, y que si llegara a obtenerlo, lo despreciaría en cierta medida con total frustración para reiniciar su travesía y conquista hacia nuevos objetos.

Para Sade incluso el alma debe ser aniquilada. El ensañamiento y encarnizamiento continuos contra las víctimas nos revelan la insaciabilidad del alma, muestra de su inmortalidad. Y a falta de poder asesinar el alma, Sade recurre al simulacro de la muerte del alma, que es el suicidio, en sus personajes; asesina el cuerpo porque no alcanza a destruir el alma. "Pues en su tedio el alma trata de darse muerte: separada de Dios, su inmortalidad se ha trocado en amargura" (Klossowski, 2005, p. 120). Sade se entrega a la búsqueda de la negación y del olvido.

Mediante esta reiteración frenética de crímenes Sade tantea la vía para alcanzar la negación absoluta que es el delirio de su razón.

\subsection{Doctrina de la Apatía}

Sade brinda sus enseñanzas a aquél digno de ser su discípulo. Para ello, mediante sus obras introduce al lector en una iniciación progresiva que culmina en la práctica de una ascesis: la de la apatía.

Las instituciones nos intimidan y nos controlan mediante imágenes, algunas previas a los actos para incitarnos a actuar o a detenernos, y otras posteriores a los actos cometidos u omitidos que nos inculcan culpa y remordimiento y nos influirán en futuras decisiones. Debemos combatir y escapar a estas imágenes de sensibilidad, asco, miedo y horror. Sade propone como solución sustituir dichas imágenes por actos.

Extingue tu alma... trata de encontrar placeres en todo aquello que alarma tu corazón: no bien alcanzada... la perfección de ese estoicismo, sentirás nacer en esa apatía una multitud de placeres nuevos, mucho más deliciosos que los que crees encontrar en la fuente de tu funesta sensibilidad... (Sade, como se citó en Klossowski, 2005, p. 99).
Los placeres encontrados en este rechazo de las imágenes sociales son incluso mayores al orgasmo, un goce inútil que hay que refrenar porque rebaja el éxtasis del pensamiento, de igual modo que hemos de controlar la expresión de cualquier otra pasión. Dejarnos arrastrar por nuestras inclinaciones no haría más que arruinar la obtención del goce supremo.

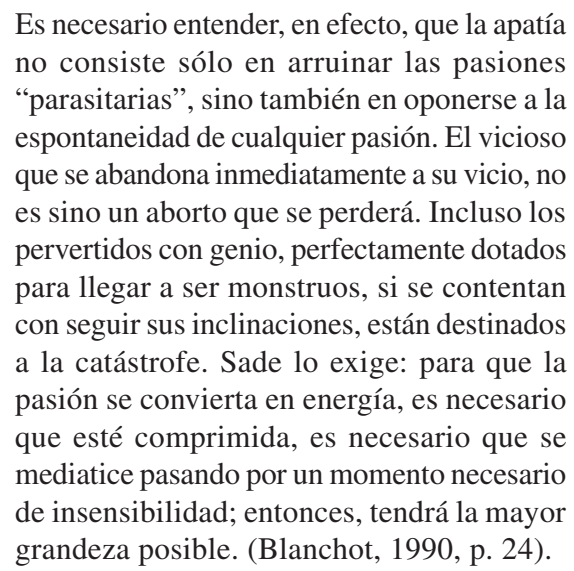

Hay que vigilar también que no asome en ningún momento la virtud, o se echará a perder todo el poder alcanzado. De lo que se trata es de matar cada ápice de sensibilidad humana.

Ante esta apología del acto y la abundancia, recordemos que justamente Freud propone que la neurosis es la contrapartida de la perversión, es decir, que mientras que el neurótico reprime, el perverso actúa.

\begin{abstract}
Es clásico el aforismo freudiano: "la neurosis es el negativo de la perversión". Negativo en el sentido de no visible, de algo que está ahí y que se haría visible si la neurosis se positivizara, al modo de una placa o un cliché fotográfico. De este modo, la neurosis es una perversión no manifiesta, no activa. (Castilla del Pino, 1973, p. 47).
\end{abstract}

Las enseñanzas de Sade nos advierten de que para mantener al monstruo dentro de la monstruosidad hay que mantenerlo fuera de la conciencia, en una transgresión permanente, para que las imágenes sociales no reaparezcan jamás, para que la nada no sea de nuevo invadida por la realidad del otro y la del yo. El monstruo debe permanecer en la apatía absoluta, es decir, en la reiteración de los actos criminales, cada cual más 
espantoso que el anterior. Es tras este fondo de tinieblas donde el libertino disfrutará de los más sublimes goces.

Todos aquellos grandes libertinos, que no viven más que para el placer, sólo son grandes porque han aniquilado en sí toda capacidad de placer. Por eso se entregan a espantosas anomalías; en caso contrario la mediocridad de las voluptuosidades normales les bastaría. Pero se han hecho insensibles: pretenden gozar de su insensibilidad, de esa sensibilidad negada, anonadada, y se vuelven feroces. (Bataille, 2013, pp. 178-179).

De este modo, en su repetición sin fin, incluso la escritura del marqués, en un inicio incitador de lujuria, horror, o ambos, pierde todo afecto e introduce al lector en la insensibilidad y la apatía.

(...) cuando leemos algunos de sus grandes textos (y en especial las célebres Ciento veinte jornadas), nos encontramos sumidos en el núcleo de un relato aterrador que, a fuerza de narrar con semejante rabia las situaciones más monstruosas, acaba produciendo el efecto contrario, hasta el punto de semejar un juego recreativo adonde irían a parar todos los fantasmas propios de la perversidad polimorfa que caracteriza el mundo de la infancia. (Roudinesco, 2009, pp. 62-63).

\section{CONCLUSIONES}

Hasta aquí nuestro intento de arrojar luz en el oscuro campo del erotismo y de la perversión, a sabiendas de que son temas que no pueden reducirse, sin ser mutilados, a un estudio específico como éste. Se añade también la dificultad de hablar de algo inherente a nuestra existencia, algo concerniente a nuestra vivencia interior. Nos preguntamos si ponerle palabras no le quita realidad. Dentro de lo posible hemos de cuidar de no desligar el erotismo y la perversión de la totalidad de la vida y la experiencia humana.

El erotismo abre una ventana a la reflexión, un interrogante acerca de nuestro ser, y no podemos cuestionar nuestro ser sin cuestionar nuestro lado oscuro. El ser humano nace con impulsos que ha de domeñar si quiere jugar en el tablero de sus semejantes, y por ello es menester prestar atención a aquello a lo que ha renunciado por tales privilegios, porque no por haberlo reprimido ha desaparecido de su interior; deja huella, y la huella marca nuestro ser. Hay por tanto en el alma humana tanto generosidad y bondad como destrucción y crueldad.

Quizá la relevancia de este estudio se halla precisamente en la no siempre admitida verdad de que en todo ser humano se encuentran, en mayor o menor medida, componentes perversos (Lin-Ku, 2016). El funcionamiento que puede ser denominado como normal por la sociedad de un momento histórico dado, coexiste siempre con lo irracional y la locura (Jorge, 2007); el imperio de la virtud es pura utopía. Como seres deseantes estamos bajo el yugo de los límites y el tormento por transgredirlos. 


\section{Referencias}

Alberti, S. \& Martinho, M. H. (2013). Sexuação, desejo e gozo: entre neurose e perversão. Psicología USP, 24(1), 119-142.

Baigorria, O. (2003). Georges Bataille y el erotismo. Madrid: Campo de ideas.

Bataille, G. (1981). Breve historia del erotismo. Montevideo: Ediciones Calden.

Bataille, G. (2000). La literatura y el mal. Recuperado de http://www.elaleph.com/libro/ La-Literatura-y-el-Mal-de-Georges-Bataille/691710/

Bataille, G. (2013). El erotismo. Barcelona: Tusquets Editores.

Bedouelle, A. (2006). Un punto de vista sobre la perversión. Recuperado de http://cms.upsa.es/sites/default/files/cuadernossalmantinos/INFORMAICON\%20GENERAL/P.\%20Web\%20 Instrucciones\%20Autores.pdf.

Blanchot, M. (1990). La razón de Sade. En M. Blanchot, Lautréamont y Sade (pp. 11-63). México: FCE.

Briole, G. (2004). Sublimación y perversión. Freudiana, 41, 109-124.

Caniato, A., Cesnik, C., \& Rodrigues, S. M. (2012). A captura da subjetividade pela violência simbólica da indústria cultural: da submissão à culpabilidade dos indivíduos. Psicología USP 23(4), 661-681.

Castilla del Pino, C. \& Sacher-Masoch, L. (1973). Introducción al masoquismo. La Venus de las pieles. Madrid: Alianza Editorial.

Chasseguet-Smirgel, J. (1998). Perversión, sexualidad, narcisismo. Revista de Psicoanálisis, 55(3), 687-690.

Colina, F. (2006). Deseo sobre deseo. Valladolid: Cuatro Ediciones.

Freud, S. (1905). Tres ensayos para una teoría sexual. En S. Freud, Obras completas, vol. 2 (pp. 1169-1237). Madrid: Biblioteca Nueva.

Freud, S. (1938). Compendio del psicoanálisis. En S. Freud, Obras Completas, vol. 3 (pp. 3379-3418). Madrid: Biblioteca Nueva.

Heine, M. (1980). Prólogo al Diálogo entre un sacerdote y un moribundo. Barcelona: Argonauta.
Jorge, M. A. C. (2007). A teoria freudiana da sexualidade 100 anos depois (1905-2005). Psychê. Revista de Psicanálise, 11(20), 29-46.

Klossowski, P. (2005). Sade mi prójimo. Madrid: Arena Libros.

Le Brun, A. (2008). Sade: De pronto un bloque de abismo. Buenos Aires: Ediciones literales.

Lin-Ku, A. \& De Santiago, F. J. (2013). Introducción metapsicológica a las perversiones. Parte I. Freud. Intersubjetivo, 13(1 y 2), 219-232.

Lin-Ku, A. (2016). La perversión sexual: psicoanálisis y filosofía (tesis doctoral). Universidad de Salamanca.

Marqués De Sade. (1997). Elogio de la insurrección. Barcelona: El viejo topo.

Puertas, P. (2017). La intimidad: una territorialidad conquistada Revista de Psicoanálisis, 80, 183-212.

Rivera, N. (2010). El diagnóstico en la clínica con niños: Psicoanálisis versus clasificaciones diagnósticas. Desenvolupament infantil $i$ atenció precoç, 31, 103-120.

Roudinesco, É. (2009). Nuestro lado oscuro: una historia de los perversos. Barcelona: Anagrama.

Ruiz, F., Ruiz, M., \& Fernández-Baca, P. (2007). Estudio psicopatológico sobre la creatividad y la perversión (la extraña inquietud en el cine de Greenaway). Analaes de Psiquiatría, 23(2), 56-61.

Stekel, W. (1954). Sadismo y masoquismo: Psicología del odio y la crueldad. Buenos Aires: Ediciones Imán.

Tabares, J. (2005). Teoría sexual y objeto en la perversión. Revista de Psicoanálisis, 46, 101-133.

Vanier, A. (2017). A criança entre sujeito e objeto. Ágora, 20(1), 135-146.

Yakeley, J. (2018). Psychoanalytic perspectives on paraphilias and perversions. European Journal of Psychotherapy \& Counselling, 20(2),1-2.

ŽIžEk, S. (2006). Deleuze. En S. ŽIžEk, Órganos sin cuerpo: Sobre Deleuze y consecuencias (pp. 19-129). Valencia: Pre-Textos. 


\section{Notas}

1 Escenario principal de la novela sadiana Los 120 días de Sodoma. 